\title{
ТЕХНІЧНI НАУКИ
}

\author{
DOI: https://doi.org/10.32839/2304-5809/2021-11-99-19
}

УДК 614.7:628.54

Літовка А.І. ${ }^{1}$, Козоріз B.O. ${ }^{2}$, Баранова А.O. ${ }^{3}$

Національний технічний університет «Харківський політехнічний інститут»

\section{ОЦІНКА ВПЛИВУ ПОБУТОВИХ ВІДХОДІВ НА НАВКОЛИШНЄ СЕРЕДОВИЩЕ}

\begin{abstract}
Анотація. В теперішній час інтенсивна господарська діяльність людини, як відомо супроводжуеться утворенням великої кількості відходів. Захоронення відходів на полігонах, а також методи їх утилізації часто приводять до значного погіршення стану навколишнього середовища. В роботі розглянута проблема впливу побутових відходів на навколишне середовище, проведено аналіз утворення даних відходів та спрогнозовано можливі об’еми їх утворення. Проблема поводження з відходами гостро стоїть у всьому світі. Не дивлячись на те, що побутові відходи займають незначну долю від загального обсягу відходів, їм приділено значну увагу. Причиною щього $є$ - екологічні, економічні та сощіальні труднощі, що пов'язані 3 процесом управління генерування відходів. В роботі проаналізовано вплив твердих побутових відходів на атмосферу, гідросферу та грунти. Розглянуто та проаналізовано світовий досвід щодо поводження та методів утилізації твердих побутових відходів.
\end{abstract}

Ключові слова: побутові відходи, навколишне середовище, полігон, епідеміологічна ситуація, джерела утворення відходів.

Litovka Anna, Kozoriz Vladlena, Baranova Antonina National Technical University «Kharkiv Polytechnic Institute»

\section{ASSESSMENT OF THE IMPACT OF DOMESTIC WASTE ON THE ENVIRONMENT}

Summary. Under current conditions, the problem of production and consumption waste accumulation is one of the leading threats to the state's environmental security. The development of separate waste collection and recycling is an integral part of improving the efficient use of natural resources and the transition to a sustainable economy. Nowadays, intensive human economic activity is known to be accompanied by the generation of large amounts of waste. An increase in cities and population and a lack of understanding in the production and use of goods is one of the reasons for the large amount of waste. In this regard, humanity is faced with the problem of environmental pollution. Landfill and waste disposal methods often lead to significant environmental degradation. The importance and relevance in modern society of the problem of the negative impact of production and consumption waste on the environment and public health are related to their daily generation, storage and disposal. Waste and its storage and disposal sites pose a toxicological and epidemiological hazard. Chemical and biological pollutants in solid waste pose a threat to soil, groundwater, surface water bodies and vegetation and may directly or indirectly cause public health problems. The epidemiological hazard of MSW increases when the system of separate collection, disposal and decontamination of waste of medical and preventive institutions is broken - more than $90 \%$ is collected and taken to a single system with MSW to landfills and dumps. The annual increase in waste generation is $4-6 \%$, requires the adoption of effective organization measures in order to obtain material and energy resources. The paper considers the problem of the impact of household waste on the environment, analyzes the generation of these wastes and predicts the possible volumes of their generation. The problem of waste management is acute all over the world. Despite the fact that household waste accounts for a small share of total waste, considerable attention has been paid to it. This is due to environmental, economic and social difficulties associated with the waste management process. The paper analyzes the impact of solid waste on the atmosphere, hydrosphere and soils. The world experience in the management and methods of solid waste disposal is considered and analyzed.

Keywords: household waste, environment, landfill, epidemiological situation, sources of waste generation.

$\Pi$ остановка проблеми. Тема дослідження $є$ надзвичайно актуальною, адже побутові відходи постійно потрапляють в навколишне середовище та негативно впливають на всю екосистему. Дослідження проблеми впливу побутових відходів на оточуюче середовище $є$ новим напрямком української наукової думки. На сьогоднішній день відсутне концептуальне бачення окресленого питання. Поводження 3 ними на сьогоднішній день $є$ глобальною екологічною проблемою для України. Це в першу чергу пов'язано з розвитком економіки, зростанням населення та розвитком сфери споживання.
Аналіз останніх досліджень та публікацій. Жииття та діяльність людини пов'язано 3 виробництвом та споживанням нової продукщії, в результаті якої утворюються тверді побутові відходи (ТПВ). Світовий об'єм таких відходів перевищуе 400 млн. т [2]. Проблемам утворення, накопичення та ращіонального використання відходів присвячено багато праць вітчизняних та закордонних вчених, зокрема: О.Ю. Амосова, О.О. Веклича, T.Ю. Голіка, Б.М. Данилишина, M.I. Долішнього, Я.О. Костенка та ін. У пращі В.В. Поповича [3] розглянуто екологічну логістику поводження з відходами та розглянуто проблему відсутності 
переробних заводів та сортувальних ліній. У роботі І.Я. Погрібного [4] приділено увагу системному поводженню 3 твердими побутовими відходами. Досліджено проблеми поводження 3 твердими побутовими відходами та визначені основні положення регіональних стратегій щодо поводження 3 відходами та проведення їх аналіз. Наукова праця Є.О. Михайлова [5] присвячена розгляду екологічної проблеми твердих побутових проблем в Україні. Наведено дані щодо структури відходів, їх впливу на довкілля та здоров’я людей.

Метою даної статті є оцінка та аналіз впливу твердих побутових відходів на навколишне середовище.

Виклад основного матеріалу. На сучасному етапі, в Україні одна людина утворює близько 1 кілограма відходів на добу, і цей показник щорічно збільшуеться [5].

При цьому обсяги утворення даних відходів щорічно збільшуються (табл. 1). Крім того, Україна належить до країн, де їх рівень утворення та накопичення $е$ найвищим [1].

Утворення відходів в Україні

\begin{tabular}{|c|c|c|c|}
\hline Рік & $\begin{array}{c}\text { Утворилося } \\
\text { (млн. т) }\end{array}$ & $\begin{array}{c}\text { Утилізовано } \\
\text { (млн. т) }\end{array}$ & $\begin{array}{c}\text { Відправлено } \\
\text { нберігання } \\
\text { (млн. т) }\end{array}$ \\
\hline 2015 & 312,3 & 92,5 & 152,3 \\
\hline 2016 & 295,9 & 84,6 & 157,4 \\
\hline 2017 & 366,1 & 100,1 & 169,8 \\
\hline 2018 & 352,3 & 103,7 & 169,5 \\
\hline 2019 & 441,5 & 108 & 239 \\
\hline 2020 & 462,4 & 100,5 & 276 \\
\hline
\end{tabular}

Ще 40 років тому в Україні майже не були пластикової тари. Продукти харчування продавалися в паперовій обгортці, залізних або скляних пляшках. Практично все це здавалося в пункти прийому вторсировини. В останнє десятиліття ситуація кардинально змінилась. Майже вся продукція що продається упакована в кілька шарів пакування, що виготовлені з синтетичних матеріалів. Дані зміни привели до появи десятків тисяч звалищ, більшість яких є несанкціонованими.
Найбільша кількість відходів розташовано на несанкціонованих звалищах Львівської та ІваноФранківської областей [6] (рис. 1).

Щорічно жителі України виробляють 11 млн. кубометрів побутових відходів, вони займають 260 тисяч гектарів - приблизно таку ж площу займає держава Люксембург. На сьогоднішній день Україна займає одне з перших місць в рейтингу країн $з$ найбільшим об'емом сміття на одного жителя (табл. 2).

\section{Моніторинг використання відходів}

Таблиця 2 в різних країнах світу на душу населення за один рік

\begin{tabular}{|c|c|}
\hline Країна & $\begin{array}{c}\text { Кількість використаних відходів } \\
\text { однією людиною за рік (т) }\end{array}$ \\
\hline Канада & 36,1 \\
\hline Болгарія & 26,7 \\
\hline США & 25,9 \\
\hline Естонія & 23,5 \\
\hline Фінляндія & 16,6 \\
\hline Вірменія & 16,3 \\
\hline Швеція & 16,2 \\
\hline Люксембург & 11,8 \\
\hline Україна & 10,6 \\
\hline Сербія & 8,9 \\
\hline
\end{tabular}

За офіційними даними в Україні утилізують або переробляють менше 6\% відходів, а в останні роки спостерігається значний приріст об'ємів паперових та пластикових відходів (табл. 3) [3]. Полігони відходів переповнені та в основному не відповідають санітарним вимогам, що в свою чергу приводить до забруднення грунтів, підземних вод та атмосферного повітря. За розрахунками, 80\% відходів можна переробляти при роздільному зборі сміття. Основою для цього є сортування відходів. Зі смішаного сміття можна вилучити для переробки лише 10-15\%. Повторна переробка сировини приводить до економії первинних ресурсів. Зокрема, 1 т макулатури зберігає від вирубування 17 дерев; 1 т пластику економить 750 кілограм надрти; 1 т склобою економить 300 кг кальцинованої соди та 1250 кг первинних матеріалів для шихти.
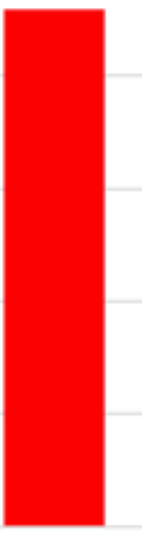

Львівська область

Рис. 1. Кількість відходів, що утворюються не несанкціонованих звалищах в Україні (тис. т) 
Таблиця 3 забезпечення санітарного та епідемічного благо-

Середня кількість утворення відходів у світі

\begin{tabular}{|c|c|}
\hline Вид відходів & Кількість відходів (\%) \\
\hline Органіка & 44 \\
\hline Папір та картон & 17 \\
\hline Пластик & 12 \\
\hline Скло & 5 \\
\hline Метал & 4 \\
\hline Гума та шкіра & 2 \\
\hline Деревина & 2 \\
\hline Інше & 14 \\
\hline
\end{tabular}

Морфологічний склад ТПВ досить різний. В побутовому смітті міститься багато фракщій. Вивчення морфологічного складу відходів необхідне для ефективної переробки та їх вторинного використання. Відсоткові відношення коливаються в залежності від умов проживання, видів діяльності та кліматичних зон.

За оцінками, в країнах з низьким рівнем доходу поводження з 93\% відходів є неправильно, в країнах з високим рівнем доходів $-2 \%$.

В середньому в світі всього $13,5 \%$ світових відходів переробляеться, 5,5\% - компостуеться. Переважна кількість відходів, що утворюються в усьому світі, не переробляються (табл. 4) [4].

\section{Структура поводження з відходами}

Таблиця 4 у середньому в світі

\begin{tabular}{|c|c|}
\hline Вид розподілу відходів & Кількість відходів (\%) \\
\hline Відкрите звалище & 33 \\
\hline Полігон & 25,2 \\
\hline Переробка & 13,5 \\
\hline Спалювання & 11,1 \\
\hline Санітарне звалище & 7,7 \\
\hline Компостування & 5,5 \\
\hline Контрольоване звалище & 3,7 \\
\hline Інше & 0,3 \\
\hline
\end{tabular}

Відходи - це будь-які речовини, матеріали і предмети, що утворилися у процесі виробництва чи споживання, а також товари (продукція), що повністю або частково втратили свої споживчі властивості і не мають подальшого використання за місцем їх утворення чи виявлення і від яких їх власник позбувається, має намір або повинен позбутися шляхом утилізації чи видалення [7].

Поводження 3 відходами регулюеться законами України "Про охорону навколишнього природного середовища", "Про відходи", "Про получчя населення", "Про поводження з радіоактивними відходами", "Про використання ядерної енергії та радіаційну безпеку", "Про металобрухт", Кодексом України про надра та іншими нормативно-правовими актами.

Відповідно до Закону України "Про відходи" [7] та інших нормативно- правових актів виділяють кілька груп відходів:

1) за сфрерою утворення - відходи виробництва та споживання і побутові відходи;

2) за ступенем небезпечності та характером впливу на навколишне природне середовище і людину - токсичні, вибухові, вогненебезпечні, радіоактивні відходи тощо (небезпечні відходи);

3) залежно від стану, в якому перебувають відходи, - газоподібні, рідинні, тверді, сумішеві.

Висновки. Вирішення проблеми негативного впливу побутових відходів на оточуюче середовище вбачаеться у виробленні відповідної програми, основними заходами якої є:

1. Удосконалення законодавства в галузі поводження з відходами.

2. Екологічна освіта населення.

3. Запровадження державної комплексної системи спостережень, здійснення топографрогеодезичних, картографічних, грунтових, агрохімічних, радіологічних та інших обстежень і розвідування стану земель і грунтів, їх моніторинг.

4. Розробка загальнодержавних і регіональних програм використання та охорони земель, документації із землеустрою в галузі охорони земель.

5. Визначення шляхів та методів удосконалення існуючої інфраструктури з управління відходами, які не суперечать інноваційній моделі.

6. Забезпечення сталого розвитку України шляхом виконання завдань, спрямованих на екологічну та ресурсну безпеку.

7. Запровадження регулярних рейсів сміттезбиральної техніки.

8. Мінімізація відходів за рахунок розроблення та впровадження технологій більш чистого виробництва, покращення екологічних характеристик продукції, зменшення обсягів пакувальних матеріалів на одиницю продукції.

9. Зниження техногенного впливу відходів на довкілля, особливо в районах концентрації промислового виробництва.

10. Розвиток вторинного ресурсокористування з відповідною інфрраструктурою що забезпечить сталу роботу переробних підприемств.

11. Удосконалення нормативно-технічного (стандарти), методичного, організаційного та інформаційного забезпечення сфери поводження з відходами.

\section{Список літератури:}

1. Налетов И. Д., Амосов Н. Т. Влияние процесса утилизации твердых бытовых отходов на окружающую среду. НЕДЕЛЯ НАУКИ СПбПУ. 2017. № 1. С. 63.

2. Алимов Р. Ш., Хисамеева Л. Р. Влияние полигонов твердых бытовых отходов и свалок на состояние водных ресурсов. Наука сегодня: фундаментальныєе и прикладные исследования. 2018. № 1. С. 14.

3. Попович Н. П., Мальований М. С., Попович В. В. Підвищення регіональної екологічної безпеки шляхом удосконалення логістичної системи поводження з відходами. Екологічні науки. 2018. № 1(20). С. 12.

4. Погрібний I. Я. До питання системного поводження з твердими побутовими відходами. Ефбективна еконоліка. 2013. № 1. С. 63.

5. Михайлова Є. О., Панчева Г. М., Резніченко Г. М. Ефективні механізми поводження з твердими побутовими відходами в Україні. Виробництво та технології. Технології захисту навколишнього середовища. 2019. № $5(151)$. C. 42 . 
6. Никифорова Н. А., Миловидова С. Н. Сравнительный анализ фракторов и стимулов переработки отходов: международный опыт. Эконолические науки. 2019. № 171. С. 144.

7. Кудина А. А., Ильина А. С., Шулепова О. В. К вопросу о необходимости переработки бытовых отходов. Актуальные вопросы науки и хозяйства: новые вызовы и решения. 2019. № 1. С. 166.

\section{References:}

1. Naletov I. D., Amosov N. T. (2017) Vliyanie protsessa utilizatsii tverdykh bytovykh otkhodov na okruzhayushchuyu sredu. NEDELYa NAUKI SPbPU, no. 1, p. 63.

2. Alimov R. Sh., Khisameeva L. R. (2018) Vliyanie poligonov tverdykh bytovykh otkhodov i svalok na sostoyanie vodnykh resursov. Nauka segodnya: fundamentalnye i prikladnye issledovaniya, no. 1, p. 14.

3. Popovich N. P. Malovaniy M. S., Popovich V. V. (2018) Pidvishchennya regionalnoi ekologichnoi bezpeki shlyakhom udoskonalennya logistichnoi sistemi povodzhennya z vidkhodami. Ekologichni nauki, no. 1(20), p. 12.

4. Pogribniy I. Ya. (2013) Do pitannya sistemnogo povodzhennya z tverdimi pobutovimi vidkhodami. Efektivna ekonomika, no. 1, p. 63.

5. Myxajlova Ye. O., Pancheva G. M., Reznichenko G. M. (2019) Efektyvni mexanizmy povodzhennya z tverdymy pobutovymy vidxodamy v Ukrayini. Vyrobnycztvo ta texnologiyi. Texnologiyi zaxystu navkolyshnogo seredovyshha, no. 5(151), p. 42.

6. Nikiforova N. A., Milovidova S. N. (2019) Sravnitelnyy analiz faktorov i stimulov pererabotki otkhodov: mezhdunarodnyy opyt. Ekonomicheskie nauki, no. 171, p. 144

7. Kudina A. A., Il'ina A.S, Shulepova O. V. (2019) K voprosu o neobkhodimosti pererabotki bytovykh otkhodov. Aktualnye voprosy nauki i khozyaystva: novye vyzovy $i$ resheniya, no. 1, p. 166. 